\title{
Historical importance of wetlands in malaria transmission in southwest of Spain
}

\author{
Arturo Sousa ${ }^{1, *}$, Fátima Andrade ${ }^{2}$, Alfredo Félix ${ }^{3}$, Vicente Jurado ${ }^{4}$, Alejandra León-Botubol ${ }^{1}$, \\ Pablo García-Murillo ${ }^{1}$, Leoncio García-Barrón ${ }^{5}$ and Julia Morales ${ }^{1}$ \\ ${ }^{1}$ Department of Plant Biology and Ecology, University of Seville, C/ Profesor García González, 2, 41012 Seville, \\ Spain.asousa@us.es; jmorales@us.es; pgarcia@us.es \\ ${ }^{2}$ Consejería de Medio Ambiente de la Junta de Andalucía, 41003 Seville, Spain; \\ fatima.andrade.ext@juntadeandalucia.es \\ ${ }^{3}$ Empresa de Gestión Medio Ambiental S. A. (EGMASA), 41092 Seville, Spain; afelix@egmasa.es \\ ${ }^{4}$ Area of Ecology, University of Pablo Olavide, 41013 Seville, Spain; \\ ${ }^{5}$ Department of Applied Physics II, University of Seville, Avda. Reina Mercedes s/n, 41012 Sevilla, Spain. \\ leoncio@us.es \\ *Corresponding author: asousa@us.es
}

Received: 9/1/09 Accepted: 23/9/09

\begin{abstract}
Historical importance of wetlands in malaria transmission in southwest of Spain

Malaria is a parasitic disease that is currently affecting a good number of countries with approximately one million deaths per year. Traditionally, this pathology has been related to wetlands and other unhealthy water bodies. It disappeared from most of Western Europe after the Second World War; however, its eradication from Spain took place later. In fact, the WHO didn't officially declare malaria in Spain eradicated until 1964, after a gradual controlled process of the illness, through the improvement of health and hygienic conditions in the country, and the fight against the vectors, the parasite, and its reservoirs. In 1913, the Spanish regions with the largest number of municipalities with autochthonous malaria were, precisely, those containing larger areas covered by unhealthy water bodies (except for Extremadura). Among them, Western Andalusia outstood as the main region with the largest area of unhealthy malaria focuses and with high mortality and morbidity rates. Within Western Andalusia, Huelva — and especially its coastal areas - has been, for centuries, one of the provinces with greater endemicity.

After the Spanish Civil War a process of reforestation with fast-growing species took place in the Coastal Aeolian Sheet of the Province of Huelva, which led to an $88 \%$ reduction of the surface covered by ponds in this territory. These lagoons had started a natural regression process by the end of the XIXth Century related to the post-Little Ice Age warming in Andalusia. The parallel evolution of malaria patients and the regression process experienced by these wetlands for the above mentioned reasons have had a determinant influence in the eradication of the disease. All of this leads us to consider the relevant role of wetlands when studying the future risk of malaria reemergence in SW Spain.
\end{abstract}

Key words: Wetlands, malaria, peat ponds, climate change, Doñana, Huelva, SW Spain.

\section{RESUMEN}

\section{La importancia histórica de los humedales del suroeste de España en la transmisión de la malaria}

La Malaria es una enfermedad parasitaria que, actualmente, afecta a numerosos países con alrededor de un millón de fallecidos al año. Tradicionalmente esta patología se ha asociado a humedales y otros cuerpos de agua insalubres. Desapareció de la mayor parte de Europa Occidental después de la II Guerra Mundial, pero en España su erradicación fue más tardía. De hecho hasta 1964, la O.M.S. no declaró erradicada oficialmente la malaria en España, tras un paulatino proceso de control de la enfermedad, mediante la mejora de las condiciones higiénico-sanitarias del país, y las lucha contra los vectores y el parásito, así como sus reservorios.

En 1913 las regiones españolas con un mayor número de municipios con paludismo autóctono eran, precisamente, las que tenían una mayor superficie de cuerpos de aguas insalubres (con la excepción de Extremadura). Entre ellas Andalucía Occidental destacaba como la principal región con la mayor superficie de focos palúdicos insalubres, y con una elevada tasa de 
mortalidad y morbilidad. Dentro de Andalucía Occidental Huelva, y especialmente su litoral, ha sido secularmente una de las provincias con mayor endemicidad.

Tras la Guerra Civil Española se inicia un proceso de reforestación en el Manto Eólico Litoral onubense, con especies de crecimiento rápido, que condujo a la reducción del $88 \%$ de la superficie de las lagunas turbosas de este territorio. Estas lagunas habían iniciado un proceso natural de regresión a finales del S. XIX asociados a calentamiento posterior a la Pequeña Edad del Hielo en Andalucía. La evolución paralela del número de enfermos de paludismo y el proceso de regresión de estos humedales, por las causas anteriores, ha influido de manera determinante en la erradicación de la enfermedad. Todo ello nos lleva a considerar el papel relevante de los humedales en el estudio del riesgo futuro de re-emergencia de la malaria en el SW de España.

Palabras clave: Humedales, paludismo, lagunas turbosas, cambio climático, Doñana, Huelva, SO de España.

\section{INTRODUCTION}

Traditionally, the presence of malaria and its prevalence have been related to the existence of wetlands. This is made evident in the etymology of the Spanish word for malaria, "Paludismo", which derives from the Latin Palus = "swamp, pool" (Corominas, 1997). Nowadays, malaria is considered as the most important among all the parasitic diseases. It affects more than 100 countries, causes approximately one million deaths per year and $40 \%$ of the world population lives in risky areas (White \& Breman, 1994; Rotaeche et al., 2001).

Malaria was eradicated from most of West Europe after the end of the Second World War (Díaz et al., 2005). Its eradication from Spain occurred later. Concretely at the beginning of the 1960s, as a general improvement of the levels of health and hygiene in Spanish society, specifically through the prevention of infections, the elimination of vectors, and its possible reservoirs, among other strategies. In fact, there are documents reporting deaths until 1959 and people suffering autochthonous malaria until 1961. This is why it was only in 1964 when the WHO declared malaria as officially eradicated in Spain (Pletsch, 1965; Bueno \& Jiménez, 2008).

Several expert panels have alerted to the risk of reemergence of malaria in temperate (and mountainous) areas, from which it had been already eradicated, as a result of Global Warming (Parry, 2000; McCarthy et al., 2001). Some researchers (Loevinsohn, 1994; Mouchet et al., 1998; Martens, 2000) have posed the possibility of relating the expansion of this pathology to cli- matic modifications or changes, such as Global Warming. Other authors question these analyses, considering them inaccurate (Reiter, 2004), labelling them as "green alarmism" (Bate, 2004) or pointing out that they disregard the historical epidemiology of the disease.

As a result of this debate, studies on the risk of malaria reemergence have been performed in several West European countries, such as Italy (Romi et al., 2001) and the United Kingdom (Kuhn et al, 2003; Chin \& Welsby, 2004). Although these results are not so definitive as their equivalent performed in Africa (Nchinda, 1998), they do contemplate certain risks related to Global Warming. In many cases, aquatic media constitute a necessary reservoir for the breeding of Anopheles, vectors of the Plasmodium parasite producing the disease. In spite of the above, the studies considering the role that wetlands are playing in this issue - as from a multidisciplinary perspective - are scarcer. Furthermore, studies approaching the issue as from a limnological perspective are still less frequent. This is how Kuhn et al. (2003) relate the reduction of malaria in the United Kingdom at the end of the XIXth century to the reduction of wetlands (among other factors). In addition, Reiter (2000) demonstrated that, during the XVIIth century, the mortality rate in England was duplicated, and even tripled, in the parishes located in swampy areas, as compared with those located elsewhere.

In view of this background, this study introduces the preliminary results of a multidisciplinary project aimed at a thorough analysis of the 
historical evolution of malaria in SW Spain and its possible connections with wetlands. Therefore, the objective of our work is to analyse some of the main data about the number of patients and deceased related to malaria in SW Spain and, more specifically, regarding the Coastal Aeolian Sheet in the Province of Huelva (Doñana and its surroundings). Besides, our aim is contributing to knowledge on one of the reasons for the historical desiccation of a good portion of the Spanish wetlands. Finally, we will attempt to contribute with some preliminary considerations referred to the recent climatic trends and to the risk of reemergence of malaria in Spain.

In order to attain these goals and considering that data is obtained from very different sources, there was a need to apply diverse methods, although always as from a multidisciplinary perspective.

\section{DATA AND METHODS}

The study is being performed on the basis of two different lines: relative information to deceased and malaria patients and the evolution of the area of the wetlands.

On one hand, the intent is to reconstruct the evolution of malaria in SW Spain (Western Andalusia). These trends need to be put into context, as far as it is possible, within the framework of the rest of Spain. For this purpose, the study of the illness is introduced both at a more general level (the whole Spanish territory) and at a more detailed one (Western Andalusia and, within the latter, the Coastal Aeolian Sheet in the Province of Huelva).

On the other hand, the data related to wetlands and other water bodies involve an approach on a scale similar to the previous one. First, we will introduce the data related to focuses of swamped areas and malaria for the whole Spanish territory. Further on, a more thorough analysis will be made on the particular case of the wetlands in the Coastal Aeolian Sheet in the Province of Huelva. The area is located in SW Spain (at approximately $37^{\circ} 10^{\prime}$ latitude $\mathrm{N}$ and $6^{\circ} 45^{\prime}$ longitude W), specifically within the boundaries of the Doñana Natural Park, between the tourist centres of Matalascañas, Mazagón and El Rocío. The
Table 1. Time period under study on historical data on malaria and wetlands. Período temporal estudiado de datos históricos de malaria y humedales.

\begin{tabular}{llcccc}
\hline & Spatial scale & XXth C. & XIXth C. & XVIIIth C. \\
\hline Malaria & Spain & Yes & Partial data & - \\
\cline { 2 - 5 } & SW Spain & Yes & Partial data & Partial data \\
\hline Wetlands & Spain & Partial data & - & - \\
\cline { 2 - 5 } & SW Spain & Yes & Yes & - \\
\hline
\end{tabular}

best-preserved formations of hygrophyte heaths of Erica ciliaris in the whole Doñana (Andalusian) environment, as well as a large number of small lagoons, are located in this area. Today, only a few disperse patches of the original community can be found; they are associated to a series of peat ponds known as Rivatehilos.

In Table 1, a synthesis is provided of both the temporal distribution of the sources of data and the spatial scale used in the analysis of the historical data about Malaria and of that related to the evolution of the wetlands.

\section{Data related to patients and deceased by Malaria}

The data referred to the XVIIIth Century were obtained from the questionnaire sent by the royal geographer Tomás López (compiled by Ruiz González, 1999) to the parish priests in all the Spanish towns. More precisely, the questions numbered four and thirteen referred to the stagnant waters in each district and to the predominant diseases therein. On the other hand, the data related to the mid XIXth Century were mostly collected from the Madoz geographic-statisticalhistorical dictionary (1848).

Both in the XVIIIth and the XIXth centuries, the historical documents, report these data as referred to "tertians" and "quartans" and not to malaria. This terminology can be extrapolated to other European countries and its relationship with the malarial fevers has been clearly evidenced by Reiter (2000), when he analysed the clinical descriptions in England during the XVIth and XVIIth centuries, and in the case of Spain, by Riera (1984), when he studied the epidemics in the XVIIIth Century. Concerning the south of 
Spain, Sousa et al. (2006a) have also performed a comprehensive review, of this very issue, for the Provinces of Granada, Huelva and Seville during the XVIIIth Century. According to Díaz et al. (2005), during the period in which Malaria was endemic in Spain, the parasite responsible for the benign tertian fevers was Plasmodium vivax, for the malign tertian was Plasmodium falciparum, and for the quartan fevers Plasmodium malariae.

With regard to the XXth Century, we have used diverse documents from the forest files in the region (compiled by Sousa \& García-Murillo, 2001) written by Manuel Kith Tassara and Gaspar de la Lama responsible for the intensive reforestation performed on the coastal sandy areas in the east of the Province of Huelva.

In order to quantify the evolution of malaria in Spain during the XXth Century, a very thorough review was made of the Documentary Archive of the "Instituto Nacional de Estadística" (National Institute of Statistics; hereinafter INEbase). These files correspond with yearly reports started in 1858 in compliance with the organic regulation issued by the General Royal Commission on Statistics (INEbase, 1858).

The first complete data about malaria for the whole Spanish territory (understood as within the current international boundaries) appeared in 1900. An additional difficulty was the fact that the name of the disease kept changing in the various yearly reports at the INEbase; during the first years, reference is made mostly to the symptoms rather than to the aetiology itself. Between the early 1900s and 1930, the disease is called "Intermittent fever and malarial cachexia". From there on, it appears under the name of "Paludismo" (malaria).

These data allowed us to rebuild the trends (in absolute numbers) of malaria patients and deceased due to malaria in Spain during the XXth Century. For the years 1949 and 19541961, for which complete data are available from all the provinces, the trends were represented cartographically (using the annual mean number of patients at a provincial scale). In order to analyse the seasonal variations of the disease, the monthly mean number of cases was also represented for the periods in which complete data are available (1949 and 1954-1960).
Considering that the main objective of the study is SW Spain, in the case of the Andalusian region, a more detailed analysis was performed of the local evolution, always depending on the data available at the INEbase. In order to study the eradication of malaria in Western and Eastern Andalusia in a differentiated manner, we have used the provincial data for deceased (1916-1930) and malaria patients (1949 and 1954-1961) in absolute numbers.

\section{Evolution of the extension of the Wetlands}

In this section, reference will be made, first, to the area occupied by malaria focuses all over Spain and, secondly, to the evolution of the areas covered by malarial wetlands in the Coastal Aeolian Sheet of the Province of Huelva.

A review was made of the data available on wetlands and other water bodies ("colecciones líquidas" in original Spanish) suspicious of being focuses of malaria transmission. In this regard, very interesting information was found concerning the whole Spanish territory, at a regional scale, for the early XXth Century. This information was collected from the advanced summary of statistical data on malaria in Spain published by the Rural Health Inspection (General Department of Agriculture) for the years 1913 and 1916 (INEbase, 1915; INEbase, 1917). In these inventories, the surface covered by malaria "focuses" in hectares was collected, understood as the swamped land requiring sanitation in order to prevent it from becoming contagious focuses and to develop some sort of exploitation. These areas exclude -as it is textually pointed out in the aforementioned inventory_ " the focuses involving rice plantations, hemp rafts, banks of channelled rivers and brooks, and road and railway ditches". Even so, this inventory of water bodies might contain some artificially swamped areas. Another innate limitation in these data is that, apparently, they exclude swamped areas that are not considered as unhealthy, thus limiting the accounting of wetlands that, potentially, are not a culture medium for the vector transmitting malaria.

These inventories also contain data on the number of municipalities with cases of malaria 
Malaria and wetlands in SW Spain

Table 2. Sources of data used for the reconstruction of the area covered by peat ponds. Fuentes de datos empleadas en la reconstrucción del área ocupada por las lagunas turbosas.

\begin{tabular}{cccccccc}
\hline Period & Fieldwork & $\begin{array}{c}\text { Aerial } \\
\text { photography }\end{array}$ & $\begin{array}{c}\text { Satellite } \\
\text { imagery }\end{array}$ & $\begin{array}{c}\text { Forestry } \\
\text { archives }\end{array}$ & $\begin{array}{c}\text { Historical } \\
\text { documents }\end{array}$ & $\begin{array}{c}\text { Historical } \\
\text { maps }\end{array}$ & $\begin{array}{c}\text { Microtopographic } \\
\text { analysis }\end{array}$ \\
\hline 1987 & $\mathrm{X}$ & $\mathrm{X}$ & $\mathrm{X}$ & $\mathrm{X}$ & - & - & - \\
1956 & - & $\mathrm{X}$ & - & $\mathrm{X}$ & $\mathrm{X}$ & - & - \\
$19^{\text {th }}(\sim \mathbf{1 8 6 9})$ & - & - & - & - & $\mathrm{X}$ & $\mathrm{X}$ & $\mathrm{X}$ \\
\hline
\end{tabular}

vs. their total number in each region, understood as the municipalities in which malaria is permanent (and not imported from other municipalities). Furthermore, they collect data on a number of malaria patients, number of deceased, morbidity, mortality, current pricing of the sites with malaria, approximate cost of works for their sanitation, lost work days due to malaria, current consumption of quinine, etc.

In the particular case of the Coastal Aeolian Sheet in the Province of Huelva, in order to study the evolution of the surface covered by peat ponds, their situation in 1987, in 1956 and in the late XIXth Century was mapped. For this purpose, data from diverse sources were used, depending on the date, as summarised in Table 2.

More precisely, we have used flights dated in 1956 (1:33000) and in 1987 (1:20000), (although we have also consulted flights dated in 1998 and in 2000), along with LANSAT-TM (1986), SPOT (1989) and LANSAT-TM (1990) satellite images.

The analysed historical data obtained from documentary archives and sources (more than 20) are essentially from centuries XVI through XX, along with 49 writings and forest reports on scrubland in the region under study (1932-1978). Besides, studies were made on over 70 historical maps especially related to the XVIIIth, XIXth and early XXth centuries.

The situation in 1987, and then in 1956, of the peat ponds to which the heathlands of Erica ciliaris are associated was mapped by means of fieldwork and through the photointerpretation of aerial photographs and satellite images. The situation at the end of the 19th Century was mapped through the interpretation of the historical documentation in the light of the situation in 1956. However, by themselves, these data do not give way to a standard mapping. Therefore, the his- torical situation was represented in conventional mapping with the help of micro relief analyses. The original contour lines at a 1:10 000 scale (from more than 250 topographic elevations) were interpolated manually, following a method developed in earlier publications (Sousa \& GarcíaMurillo, 2003). This method enables contour lines to be obtained approximately every 2 metres, from which a hypsometric map is constructed, revealing the original situation of the former large lagoons, thereby corroborating the historical sources.

\section{RESULTS}

\section{Issues related to the historical distribution of malaria in Spain}

Although the origin of the disease is much older, the first known European malaria pandemics date back to the XVIth Century (1557-1558) according to Sáenz \& Marset (2000). At the end of the XVIIIth Century, malaria was markedly epidemic in Spain (Rico-Avelló, 1950; Sousa et al., 2006a). During the XIXth century, it was still significantly virulent, although tending to be more severe in certain endemic regions that were primarily related to different types of inland aquatic ecosystems. During the XXth century, the drying up of wetlands, the improvement in hygienicsocial conditions, and the creation in 1924 of the Central Anti-Malaria Commission produced a slow reduction of the disease.

According to the data in the INEbase (INEbase, 1955), an important rise in the number of malaria cases took place in Spain right after the Civil War; the greatest mortality took place during the years 1941, 1942 and 1943, when the number of deaths was tripled. In the case of the Ebro 
Delta, although the rise coincided with an increase in the area covered by rice plantations, this does not seem to be the cause for the new epidemic outbreak according to Fabregat (2007). Data obtained from INEbase source reveal that, as from the 1950 decade, there were many diseases whose morbidity was reduced, although the most pronounced decrease took place in malarial fevers. In the mid '50s, Seville, Huelva and Cádiz - in this order - were the three provinces in Spain with the largest number of malaria cases, highly distant from the rest, thus turning Western Andalusia into an important focus of endemic malaria. In 1959, the last individual decease due to autochthonous malaria occurred in Spain, while the last registered infected individuals in the provinces of Cáceres, Huelva, Salamanca and Toledo (INEbase, 1961; INEbase, 1964). This pathology evidences a markedly rural distribution, which might be related to the proximity of wetlands and other swamped areas acting as reservoirs for the vector transmitting the disease. 2514 cases were reported in 1955, among which only $20(0.79 \%)$ belonged to provincial capitals, $160(6.36 \%)$ to municipalities with more than 20000 inhabitants and, contrarily, $2334(92.84 \%)$ to municipalities with 20000 or less inhabitants.

The data in the INEbase do not always contain the complete number of malaria patients or deceased in the provincial, regional or national environments. Consequently, there was a need to find out whether the data on malaria patients or deceased can be used indistinctly, so as to reach a conclusion on the distribution of the main focuses of the disease. In order to solve this issue, an analysis was made of the correlation between absolute number of malaria patients and number of deceased at a regional level throughout Spain in 1913. This year was selected for the following three reasons: at that time, eradication work had not been started by the Central Anti-Malaria Commission, it was a year with a high number of deceased (almost 2000 deaths) and, finally, because this is a year for which data are available on the surface covered by malarial swamped areas throughout Spain.

The analysis of provincial patients versus deceased in Spain in 1913, $R^{2}=0.9091$, confirmed the expected correlation of both variables and, therefore, any of them could be used as a tool for exploring the evolution of the disease.

A different although supplementary issue is the distribution of the number of malaria patients due to malaria in the whole Spanish territory. For this purpose, knowing how the disease was distributed during the last few years and before its definite eradication became especially interesting. As the pathology starts to be under control, the focuses with the greatest endemicity could be identified more clearly. As these focuses became known, an attempt could be made to establish if there was a relationship with the surface and the number of swamped areas. Figure 1 shows the provincial distribution of patients due to malaria in Spain during the 1949-1961 period.

Although the number of cases decreased significantly as from 1949, when these years were analysed separately, in general terms, the pattern of provincial distribution of malaria patients in Spain remained constant. SW Spain continued to be the main focus of malaria. To be noted are the low course of the Guadalquivir (Seville, Cádiz and the coastal sandy areas of Huelva), along with Extremadura (especially Cáceres) and Ciudad Real. Also the Spanish Mediterranean coastal areas (especially Murcia) were included among them. They all correspond with provinces that have had or still have important swamped areas.

\section{Malaria focuses and wetlands in Spain}

The INEbase contains detailed data on diseases for which reporting was mandatory, such as malaria. The same source does also provide interesting data related to the presence and the distribution of the malaria focuses (INEbase, 1915; INEbase, 1917).

The information provided is highly relevant because, on one hand, a quantification of the Spanish wetlands is made available, far before than that performed by Pardo (1948), in a comprehensive and systematic manner. On the other hand, it allows to relate the distribution of wetlands with that of malaria, especially because it refers to dates prior to the start of the anti-malaria campaigns all over Spain.

Obviously, these data are not complete because they refer, exclusively, to areas with malaria and unhealthy due to the presence of water bo- 


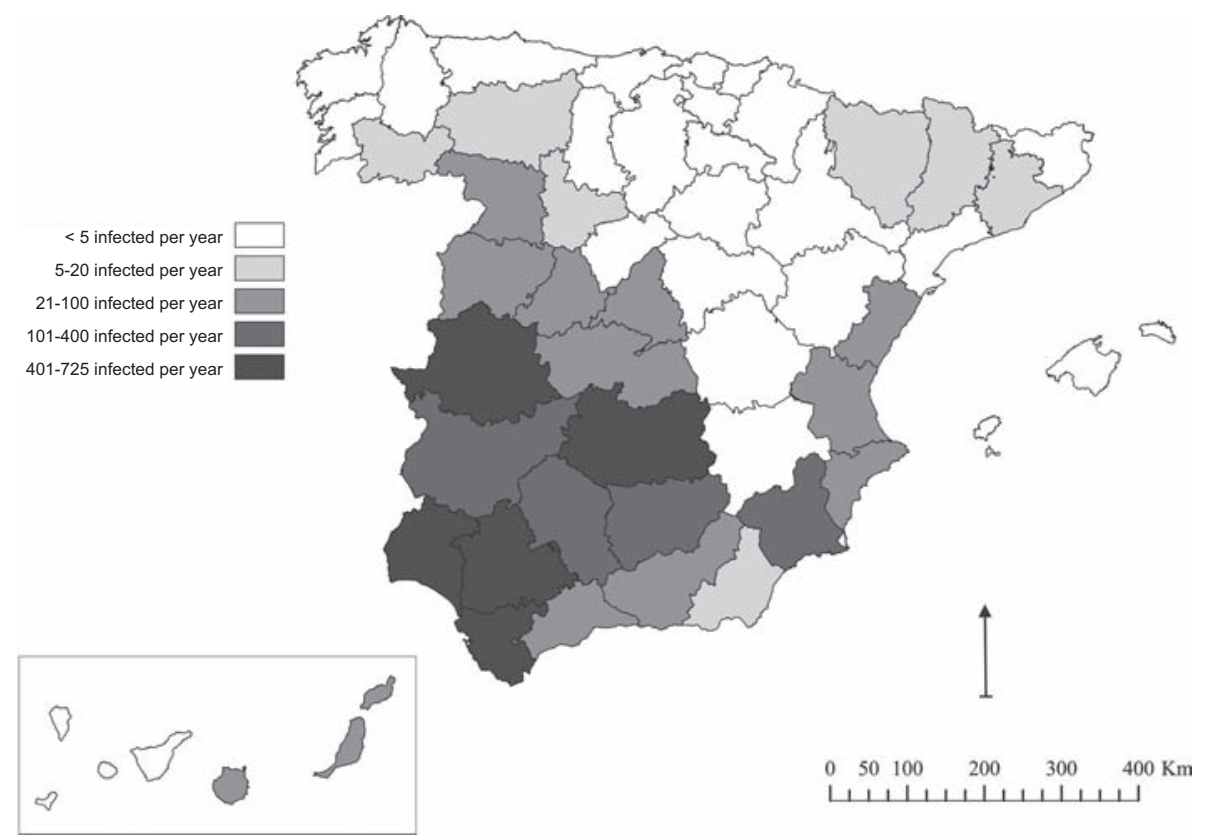

Figure 1. Mean number of malaria patients per province in Spain during the 1949-1961 period. Media provincial anual de enfermos por malaria en España durante el período 1949-1961.

dies. Even so, they constitute a novel source of indirect limnological information by providing a first historical image of the distribution of a certain group of wetlands in Spain in the early XXth Century. Figure 2 shows the regional distribution of malarial focuses, understood as potentially unhealthy water bodies but excluding many water accumulations of an anthropic character, some of which can act as important habitat for anophelines. For instance, rice fields, road and railway ditches, and hemp rafts; non-channelled brook and river banks are neither included.

In 1913, the total malarial surface in the Spanish territory that was more or less swamped for diverse reasons reached 341070 ha, a figure that was reduced to 313200 ha by 1916. As can be seen in figure 2, Western Andalusia outstands as the region with the greatest surface of malarial focuses (above 200000 ha) followed by La Mancha and Levante. However, the malaria focuses in the latter region evidenced a strong reduction during the next two years, as can be seen in figure 2 .

The same source includes other social and health-related data (the price of malarial land in pesetas, the cost of sanitation works, the yearly consumption of quinine, an assessment of the labour days lost due to malaria, etc.). Figure 3 shows the regional percentages of municipalities with autochthonous malaria in 1913 and 1916.

These data do neither allow us to establish a statistically significant correlation between the regional percentages of malarial municipalities and the surface of malarial focuses. However, when figures 2 and 3 are compared, it can be seen that, as a general rule, the regions where malaria is spread to a higher percentage of municipalities evidence a larger surface involving malarial areas or focuses. Definitely, Extremadura is an exception in this trend with $86.7 \%$ of its municipalities suffering malaria. Except for this case, the regions with the largest surfaces covered with unhealthy water bodies (Western Andalusia, La Mancha and Levante) are the ones involving a greater density of malarial municipalities (between 40 and $60 \%$ of the whole regions).

Another interesting issue is the seasonal distribution of the disease. Monthly malaria patients data are available for all the Spanish territory corresponding to 1949 and the 1954-1960 periods. An individual analysis for the various years re- 


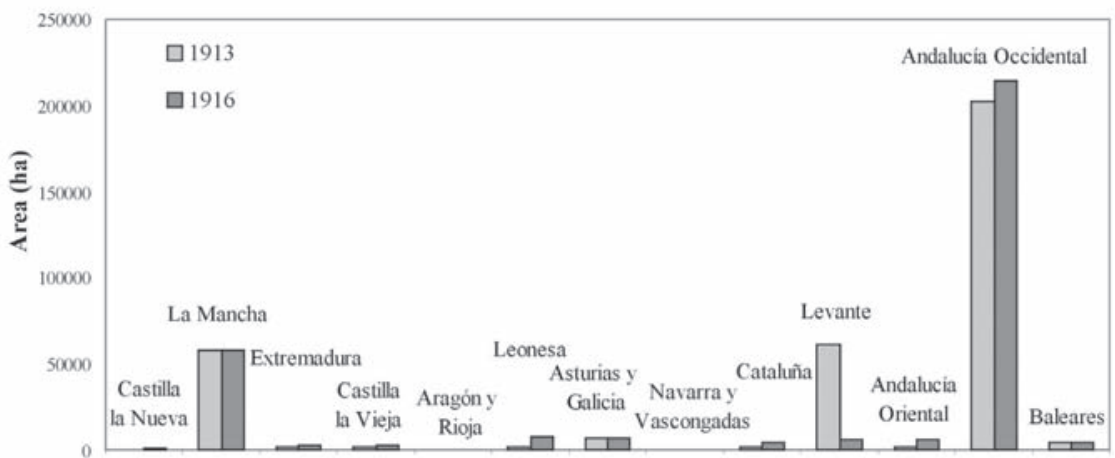

Figure 2. Regional distribution of malaria focuses in Spain in 1913 and 1916. Distribución regional de focos palúdicos en España en 1913 y 1916.

veals a very homogeneous behaviour, regardless if referred to years with a high rate of patients, such as 1949 (33,919 cases), or to those with a scarce rate, such as 1960 ( 31 cases). Although the disease is present throughout the year, the number of cases increases during the warmest months and decreases during the coldest ones. This is a relevant issue because of the tentative relationship that could exist between the disease and climatic variables such as mean or minimal temperature and rainfall. In figure 4 we have summarised the mean seasonal distribution of malaria in Spain during 1949 and the 1954-1960 period.

In figure 4 it can visualise how - at least during the second half of the XXth Century - the number of malaria patients is especially associated to the summertime. The pattern of maximum and minimum temperature is fundamental for the vector and parasite activity cycles as gathered by (Díaz et al., 2005). In a specific case of the eastern coastal area of Huelva, Anopheles atroparvus show a distribution that continues from June until the end of September, although the more numerous populations are located in June and August (López, 1989). According to Sallares (2006) environmental changes altering mosquito breeding sites in coastal wetlands had a substantial influence on the history of malaria in many parts of Europe during the Holocene.

\section{The case of wetlands in the surroundings of Doñana and malaria}

In the late XVIIIth Century, malaria (tertian and quartan fevers) was the most frequent pathology in most of Andalusia. No relationship could be

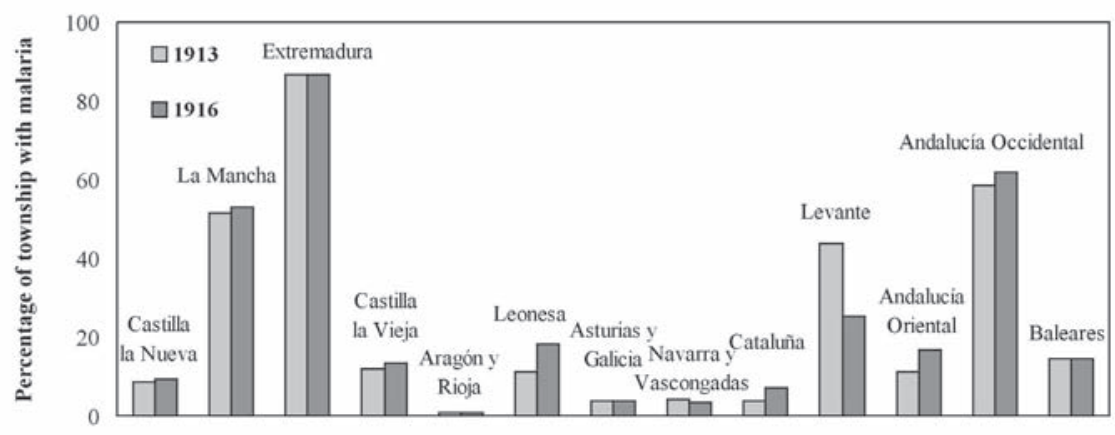

Figure 3. Distribution, in percentage terms, of Spanish municipalities with autochthonous malaria with regard to the total number of municipalities in each region. Distribución en España, en porcentaje, de municipios con paludismo autóctono respecto del total de municipios de cada región. 


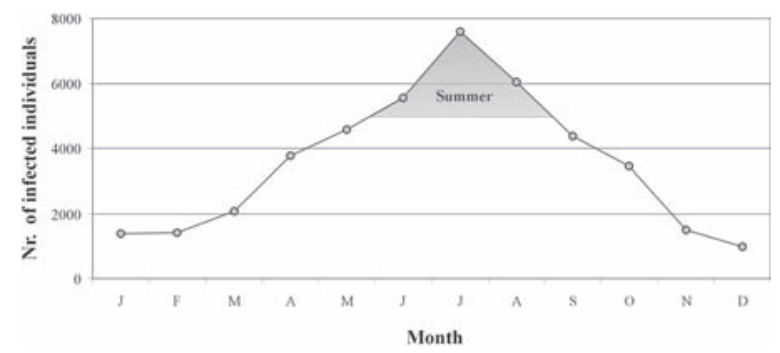

Figure 4. Monthly distribution of malaria patients due to malaria in Spain during the 1949-1960 period. Distribución mensual del número de enfermos por malaria en España durante el período 1949-1960.

established for this period between malaria and the distribution of wetlands, considering that, in the late XVIIIth Century (1786-1792), a great epidemic of tertian fevers ravaged the whole Spanish territory (Segura, 1990). According to Rico-Avelló (1950), this one was the most severe malaria epidemic in Spain, surpassing the outbreaks occurred after the First World War and after the Spanish Civil War.

In the XIXth Century, the data published by Madoz (1848) and Heraso (1890) do already highlight that the malarial fevers had acquired greater endemicity, due to the fact that they had started to be limited and concentrated in the most swampable areas. Thus, in connection with the Coastal Aeolian Sheet in the Province of Huelva, Heraso (1890) points out: “... additionally, a good number of infected lagoons and puddles are scattered on it, which fill up the environment with unhealthy malarial vapours" (translate to English). However, malaria continues to be a frequent disease all over Spain.

Specifically, the municipalities of the eastern coastal area of the Province of Huelva, in which lagoons and marshlands are present or closer (Almonte, Moguer and Palos), are the ones where the presence of malaria appears more clearly. A comparative summary of the situation in these municipalities, within the environment of the Coastal Aeolian Sheet in the Province of Huelva, during the XVIIIth and XIXth centuries, is shown in Table 3.

During the XXth Century, more-or-less complete statistics were already available, allowing the quantifying of the patient numbers and deceased due to malaria all over Spain. The evolution of the disease in the south of Spain confirms the greater significance of the focuses located in Western Andalusia, as opposed to those in Eastern Andalusia. These results are consistent with the estimated size of the areas involving potentially unhealthy marshy or swamped locations in both regions in 1913 y 1916 (Fig. 2). As it can be seen in figure 5 , from the points of view of both deceased and patients, Western Andalusia was a much more affected region than Eastern Andalusia throughout the XXth Century.

This trend remains unchanged in the Coastal Aeolian Sheet of the Province of Huelva until the

Table 3. Presence of tertian and quartan fevers in the municipalities of the Coastal Aeolian Sheet of the Province of Huelva during the XVIIIth and XIXth centuries. Presencia de fiebres tercianas y cuartanas en los municipios del Manto Eólico Litoral onubense durante los siglos XVIII y XIX.

\begin{tabular}{lll}
\hline $\begin{array}{l}\text { Municipality } \\
\text { Almonte }\end{array}$ & $\begin{array}{c}\text { Most frequent diseases according } \\
\text { to Tomás López (1785-1790) }\end{array}$ & \multicolumn{1}{c}{$\begin{array}{c}\text { Most frequent diseases according } \\
\text { to Madoz (1848) }\end{array}$} \\
Bonares & Tertian diseases & $\begin{array}{l}\text { Tertian diseases and some pneumonias produced by the vapours of } \\
\text { the swamps and the warmth of the sand }\end{array}$ \\
Tertian diseases & $\begin{array}{l}\text { Tertian diseases caused by humidity (winter) and by inflammatory } \\
\text { fevers (summer) }\end{array}$ \\
Huelva & Tertian diseases or periodical fevers & Tertian diseases and pneumonias \\
Lucena del Puerto & Tertian diseases or periodical fevers & -
\end{tabular}




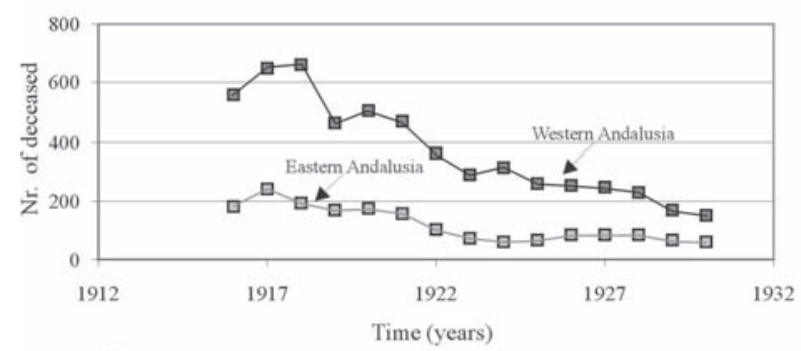

(A)

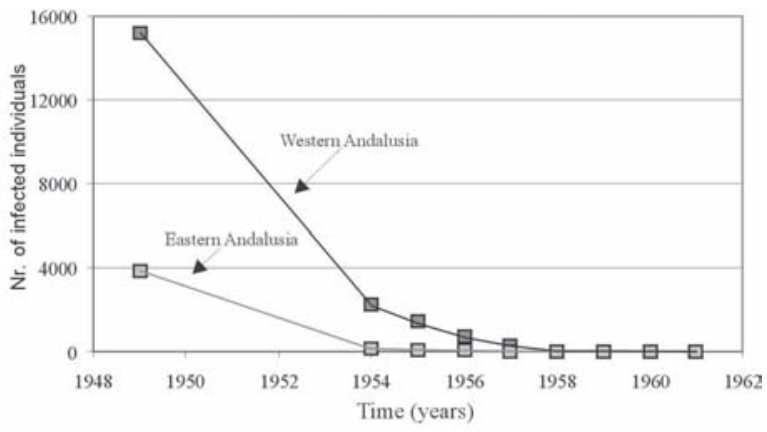

(B)

Figure 5. (A) Number of deceased due to malaria in Andalusia during the 1916-1930 period. (B) Number of malaria patients due to malaria in Andalusia during the 1949-1961 period. (A) Fallecidos por malaria en Andalucía durante el período 1916-1930. (B) Enfermos por malaria en Andalucía durante el período 1949-1961.

first half of the XXth Century (De la Lama, 1941). According to Ojeda (1987), malaria could be eradicated in Almonte (Huelva) between 1957 and 1959.

The causes for this back move of malaria in the Coastal Aeolian Sheet of the Province of Huelva appear to be clearly related to a process of local reforestation with pines and eucalyptus (Sousa \& García-Murillo, 2001). This process led to a definite desiccation of most of the lagoons in this region. Just before the Spanish Civil War, this territory of quaternary sandy areas, riddled with swarms of lagoons, was considered as an inhospitable and unhealthy place, a barren waste land. This is why this ambitious reforestation process was started; in the words of one of its brewers, its objective was "... that, once reforested, this area - which is currently arid and unhealthy due to malaria - can be turned into a magnificent and healthy pine forest [...] thus providing the region with new benefits" (Kith, 1936). Still in the middle of the XXth Century, the impression of insalubrity caused by this area to one of the managers of the reforestation process was captured in this description (translate to English): "... in that huge and depressing loneliness that was only disturbed by the buzzing of the thick cloud of mosquitoes, potential carriers of malaria, that enveloped us both horses and riders" (De la Lama, 1951).

The natural transmission of malaria occurs through the bite of mosquitoes of the genus Anopheles of which, although 70 species transmit malaria, only around 40 are of medical importance. Anopheles gambiae and Anopheles fu- nestus are the main vectors in tropical Africa. The only potential vector still present in Spain is Anopheles atroparvus the populations of which is still widely distributed throughout large areas. Anopheles labranchiae, the other vector involved in the transmission of malaria, disappeared from the Southeast of the Peninsula in the 70s of XXth (Díaz et al., 2005).

The situation of the Doñana Natural Park wetlands as reservoirs for the anophelines, vectors of the protozoan producing the malarial fevers, appears clearly in the documents dated in this period. A proof of this is the report written by Gaspar De la Lama for the National Forest Patrimony on the situation in the region. In his report, De la Lama (1941) includes a budget involving a series of expenditures for struggling against malaria. To this end, he proposes: the protection against mosquitoes in home windows, containers with "citronella oil", whose strong odour frightens mosquitoes off, and analyses and treatments for the affected workers using quinine in case of infection. From a limnological point of view, the most interesting issue is that, concerning the lagoons, he proposes silting up - should this be possible considering its cost-, the introduction of Gambusia holbrooki, a fish introduced in Spain in 1921 (Elvira \& Almodóvar, 2001) that feeds on the mosquito larvae - and, if possible, pouring "Schweinfürt green" (a larvicide derived from arsenic) into the lagoons every two weeks.

This was how a vast and ambitious reforestation process was started when the region named "Forest 


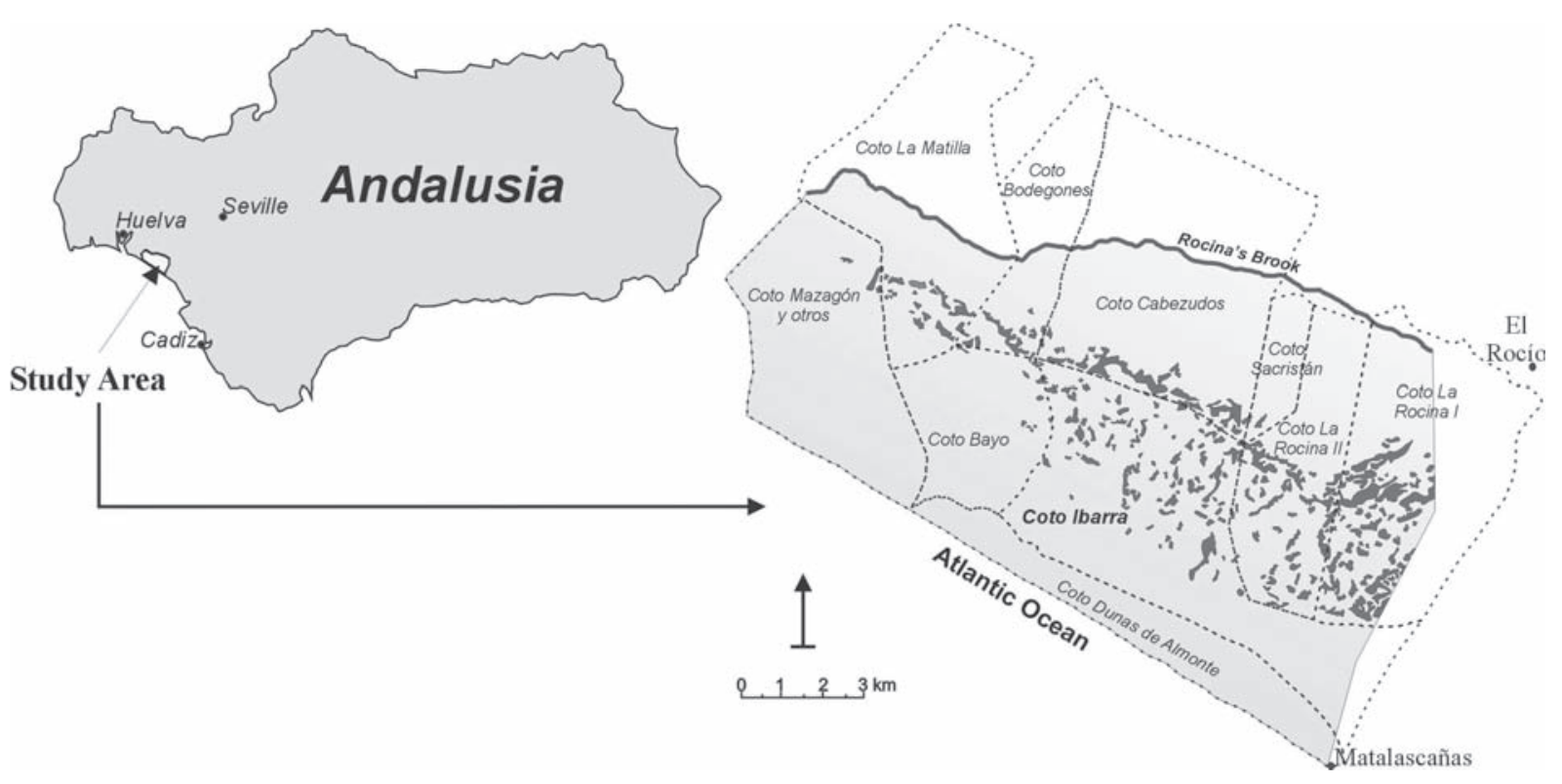

Figure 6. Location of the peat ponds of the Doñana Natural Park (Abalario sector) obtained during a flight in 1956. It does also represent the distribution of the estates in the Forest Area of the Southeast of Huelva. Developed from Sousa et al. (2006b), modified. Situación de las lagunas turbosas del Parque Natural de Doñana (sector Abalario) elaborada a partir del vuelo de 1956. También se representa la distribución de los cotos de la Comarca Forestal del Sureste de Huelva. Modificado a partir de Sousa et al. (2006b).

Land of the Southeast of Huelva" was declared of "National Interest" and practically the whole territory was planted with fast-growing species. Nowadays, the evolution of this reforestation process is well known thanks to the studies performed by Espina \& Estévez (1993), Sousa \& García-Murillo (2001), and García Murillo (2006), among others. The impact of forest monocultures (especially that of eucalyptus in the areas with peat wetlands) was highly significant. In fact, the surface covered by these types of ponds was reduced $88.2 \%$ (1352.5 ha) during the 1956-1987 period.

In 1956, most of the ponds located within the current Doñana Natural Park, to which De la Lama referred, were peat ponds. This explains the relationship between malaria and the peat wetlands in the eastern coastal area of the Province of Huelva during this period. With regards to the lagoons at Coto Ibarra, in a technical report, De la Lama (1941) stated "... most of them keep holding water during the summer, but they greatly facilitate the reproduction of mosquitoes (anopheles) and the resulting spread of malaria" (translate to English). Figure 6 shows an image of the situation of peat ponds in 1956, with heath vegetation [community of Erico ciliaris-Ulicetum (minoris) lusitanicus] at Coto Ibarra (and at the rest of the scrubland in the Forest Area of the Southeast of Huelva).

Since the mid '50s, the zone of Coto Ibarra was made up of an important wetland. In fact, the man in charge of the desiccation of these wetlands, Gaspar de la Lama pointed out that, when he visited Coto Ibarra for the first time, all of it was one inch deep and the horse was squelching around (García Murillo, pers. comm., 2002). The surface of this whole set of peat ponds had already been reduced drastically in 1987 . The peat ponds that, in 1956, covered an area of 1533.0 ha distributed in 178 patches (Fig. 6), had been reduced to 30 patches or polygons covering 180.5 ha in 1987 . This means a retreat rate of $43.6 \mathrm{ha} /$ year.

The desiccation effect produced by the high evapotranspiration of the eucalyptus monocultures led to a fall in the height of the water-table, as confirmed by hydrogeological studies (Trick \& Custodio, 2003). This process led to the desiccation of most of the peatlands dominated by Erica 
ciliaris and Ulex minor, and their replacement by a hygrophyte scrub (dominated by Erica scoparia and Ulex australis), better adapted to seasonal swamping (Sousa \& García-Murillo, 2003).

If we go back to the late XIXth Century, the Rivatehilos peat wetlands covered an even larger area than in 1956. Between the end of the XIXth Century and 1956, the surface covered by the ponds of Rivatehilos (within the current Doñana Natural Park) was reduced from 1738.9 to 1533.0 ha (retreat rate of 2.4 ha/year). As demonstrated by Sousa et al. (2009), the anthropic impact was not relevant during this period. However, this reduction coincides, as it was pointed out by Sousa \& García Murillo (2003) and Sousa et al. (2006b), with the end of the third and last humid pulse of the Little Ice Age (hereinafter LIA) in Andalusia. These results are in agreement with the spread of malaria in the municipalities of the Coastal Aeolian Sheet of the Province of Huelva at the end of the XIXth Century, as summarised in Table 3.

All the above leads us to think that the situation could be more or less similar in most of the wetlands of the Doñana National Park and in those of Palos and Las Madres, which are also located within the eastern coast of the Province of Huelva (municipalities of Palos de la Frontera and Moguer). With regard to the latter ponds, the data obtained from interviews with Mr. Pedro Weickert (an ornithologist who used to know and visit the Palos and Las Madres lagoons in the middle of the XXth Century), as compiled by Fernández-Zamudio (2005), are quite enlightening. According to these data, at least until the ' 40 s, the great peatland of Las Madres lagoon was a site rejected by the local population because diverse hazards were feared, among them the possibility of catching malaria. The reverse situation occurred with the lagoons at Palos that, apparently, had a certain social prestige in so far as hunting activities were concerned (Fernández-Zamudio et al., 2007).

Ramsdale and Snow (2000) mention populations of Anopheles atroparvus in the Province of Huelva. Specifically López (1989), has found populations of this species on the Huelva coastline in the "Lagunas de Moguer I and II", "Arroyo Galarín" marshlands, in the "Cabeza del Bu- jo" marshlands, "Bellavista" marshlands, "Laguna del Portil" (and in the adjoining residual pool) and in the "Estero de la Cruz" marshlands. This author presents the special larvae habitats of the Anopheles atroparvus, on the Coastal Aeolian Sheet in the Province of Huelva, as small, freshwater lagoons, although also with low levels of saltwater (high saline content can impede the hatching of the eggs), with shallow submerged or emerged vegetation, (temporary or permanent lagoon borders) with scarce or no contamination. This description fits well with the above mentioned lagoons, although during the period of studies sampled by López (1989), they were densely occupied by eucalyptus, as already commented.

\section{DISCUSSION}

\section{Malaria and wetlands in Spain}

The possible relationship between the extension of wetlands and the proliferation of malaria has been lengthily discussed in Spain. There is a good number of historical references on this topic; among them, the strong polemics held during the XVIII ${ }^{\text {th }}$ Century with regard to the expansion of the rice fields at Albufera de Valencia, as they were considered as harmful for public health (Riera, 1982). This argument is maintained until today, as point out by Fabregat (2007), and only a profound knowledge of the relationship between the different components of the illness cycle (vector, parasite, and rice fields) has permitted us to overcome, in part, the contradictions (Sáenz \& Marset, 2000; Fabregat, 2007).

In the late XIXth Century and the early XXth Century, these polemics bore, partially, a policy aimed at the desiccation of swamped and unhealthy areas. Thus, wetlands such as the Padul peatland in Granada (Pérez-Raya \& López-Nieto, 1991) were desiccated. This issue does also arise in the origin of the process of reforestation of the Coastal Aeolian Sheet in the Province of Huelva and in the resulting desiccation of large areas of peatlands. As it is pointed out by Cirujano \& Medina (2002), often, malaria has been the reason put forward for the desiccation of the wetlands. 
Rico-Avelló (1950) states that Spain contained areas with a marked endemic prevalence that was affected by a periodical fluctuation until it acquired epidemic features all over the country. According to Pittaluga's data compiled by Rico-Avelló (1950) and Fernández Astasio (2002), between 1903 and 1918, the regions affected by malaria were especially Extremadura, Murcia, Andalusia, Toledo and Ciudad Real. This distribution is similar to the one existing during the epidemic of the post-Spanish Civil War (1939-1943; Rico-Avelló, 1950). Therefore, as a general rule, these sources agree with the provincial mapping on patients for the 1949-1961 period developed for this study (Fig. 1).

These data agree with the distribution of malaria focuses in Spain in the early XXth Century. In fact, as it can be seen in figure 2, Western Andalusia, followed by Levante, plus La Mancha, are the regions involving the largest areas affected by malaria.

\section{Evolution of malaria in the Coastal Aeolian Sheet of the Province of Huelva (SW Spain)}

In the early XXth Century, Western Andalusia was the main focus of malaria in Spain, in so far as its area was concerned. This was an additional factor to the fact that Andalusia contains one of the richest patrimonies of wetlands in Spain and the European Union, with approximately $56 \%$ of all the Spanish floodable areas (Consejería de Medio Ambiente, 2002).

According to the Consejería de Medio Ambiente (2002), the Province of Huelva concentrates up to $77 \%$ of the area of the Andalusian wetlands. This very source estimates that the marshlands of the Guadalquivir by themselves have lost 138000 ha. These data can be compared with the area covered by the malaria focuses in Western Andalusia in 1913 (202,360 ha) and with the reduction of the Rivatehilos peat ponds started in the late XIXth Century (1558.5 ha).

The results of this study evidence how, in the particular case of the peat ponds located in the Coastal Aeolian Sheet of the Province of Huelva, its regression has been related to the eradication of malaria. There are several documents evidencing that the startup of production in this territory, previously considered as waste ground
(Espina \& Estévez, 1993), was the main objective of intervention upon this space in the Province of Huelva. Notwithstanding, this process was also stimulated by the eradication of malaria from an area that was historically endemic (Kith, 1936; De la Lama, 1976).

Consequently, these ponds and other wet areas were subjected to an exhaustive anti-malaria treatment, along with a gradual process of desiccation. First, species of eucalyptus more resistant to swamping (such as Eucalyptus camaldulensis) were implanted, followed, as the ponds bowls dried up, by less-tolerant species (such as Eucalyptus globulus; Burguers, 1949), until most of the peaty formations were dry. In parallel, diverse activities were performed in a specific struggle against the reproduction of the Anopheles mosquitoes in the ponds (De la Lama, 1941).

Thus, the process of desiccation of the peatlands in the eastern coastal area of the Province of Huelva contributed effectively (along with other health factors) to the eradication of malaria from the coastal areas of the Province between the late '50s and the early ' 60 s. The presence of the aforementioned wetlands, along with other water bodies, explains, to a great extent, why Huelva was one of the last provinces in eradicating malaria.

The desiccation of these peat wetlands was also related to the LIA in Andalusia (Sousa \& García-Murillo, 2003) and, especially, with the post-LIA warming (Sousa et al., 2006b). These results contrast with the thesis related with the LIA developed by Reiter (2000) in England. This author argues that there is no relationship whatsoever between the algid phase of this climatic period in England and the prevalence of malaria, so as to prove that there is no relationship between climatic changes and malaria, at least in the past. However, Reiter (2000) considers that the effects of the LIA were highly different throughout the world and, consequently, that it was not a climatically homogeneous period in all latitudes. Thus, what in the most northern latitudes implied a colder period, implied a series of wet pulses among drier pulses in more southern latitudes, as in Andalusia (Rodrigo et al., 1999) or the Iberian Mediterranean coast (Barriendos \& Martín-Vide, 1998). 


\section{Considerations concerning the risk of reemergence of malaria in Spain}

There is a good number of factors coming into play in the analysis of the risk of reappearance of introduced malaria in Spain. Most of such factors exceed the scope of this study. Although autochthonous malaria has been already eradicated from Spain, imported malaria (especially by immigrants and tourists) is still present. Thus, the Spanish epidemiological pattern is similar to that in the rest of the surrounding European countries, where a growing trend is observed in this type of malaria (Rotaeche et al., 2001).

A priori, Western Andalusia (and, more precisely, the eastern coast of the Province of Huelva) is an area involving factors that might favour future outbreaks of introduced malaria (that is, native mosquitoes with tropical parasites): the presence of wetlands suitable for the reproduction of the vector, the presence of nuclei with Anopheles atroparvus (López, 1989), being an area of transit for emigrants carriers of the disease, etc.

SW Spain has experienced a decrease in spring rainfall and an increase in the mean minimum temperatures since the beginning of the 20th century (García-Barrón \& Pita, 2004; García-Barrón, 2007). Loevinsohn (1994) provided evidence of the relationship between an increase of the mean minimum temperatures and an increase in the incidence of malaria in Rwanda.

On the other hand, cases of introduced malaria have appeared in Italy (Baldari et al., 1998), as well as one case in Spain (Cuadros et al., 2002), although in the opinion of Díaz et al. (2005) it may be a case of airport malaria caused by the proximity of the aerodrome at Torrejón de Ardoz. In the opinion of Tran et al. (2008), although several models have predicted a potential increase of malaria in Europe, there is a general agreement that the risk is very low under current socio-economic conditions. However, occasional autochthonous cases recently reported in Italy, Spain, Germany and Greece, highlight the importance of updating the current distribution of the potential European malaria vector as a preliminary "mapping risk" step toward predicting future scenarios.
An additional factor to be considered is that of the current chances for large population movements. In the opinion of Rico-Avelló (1950), this was one of the factors that boosted the epidemic during the post-Spanish Civil War. In the early XXth century, the flow of emigrants from the Spanish southeast to Algeria did also favour the spread of the disease (Perdiguero, 2005). More recently, outbreaks have occurred in the countries of the former USSR generated by the troops returning from Afghanistan (Díaz et al., 2005). The presence of important demographic flows, along with the proximity of the African coast, imply additional factors to be considered when analysing the risk of reemergence.

In the preliminary report on the impact of climatic change in Spain (Díaz et al., 2005), the reestablishment of malaria is considered as highly improbable (as far as a drastic deterioration of the social and economic conditions does not take place). However, in the same report, local and sporadic transmission is not discarded, and neither is the possibility for African vectors susceptible to the tropical Plasmodium strains to invade Spain the southern territory of the Iberian Peninsula. As Bueno \& Jiménez (2008) state, although the socio-economic level of Spain does not appear to foreshadow the possible re-emergence of the disease in the short and medium term, the presence of well-established populations of anophelini and plasmodium gametocytes circulating in a certain percentage of the human population does appear to warrant the continuation of the current status of epidemiological surveillance. Moreover, the globalisation of markets and the emerging process of climate change could enable the colonisation of our territory by part of the Anopheles species that transmit human plasmodiosis in tropical and subtropical regions.

On the other hand Hay et al. (2002a, 2002b), suggest that claimed associations between local malaria resurgences and regional changes in climate in East Africa are overly simplistic. Therefore the most parsimonious explanation for recent changes in malaria epidemiology involves factors other than climate change (like variations in environmental, social and epidemiological fac- 
tors). However, this interpretation is not exempt from controversy (Patz et al., 2002).

In our opinion, all the above factors lead to think of a very low risk that is only limited to little outbreaks of introduced malaria. However, the history of the disease suggests the need to keep alert and to increase research efforts as from a multidisciplinary approach. This very idea is shared by Lindsay \& Thomas (2001) with particular reference to the marshland areas in southern England.

\section{ACKNOWLEDGMENTS}

This study was financed by the Spanish Ministry of Education and Science - Project CGL200607194/BOS "Recent climatic changes and risk of Malaria reappearance in SW Andalusia (Spain)".

\section{REFERENCES}

BALDARI, M., A. TAMBURRO, G. SABATINELLI, R. ROMI, C. SEVERINI, G. CUCCAGNA, G. FIORILLI, M. P. ALLEGRI, C. BURIANI \& M. TOTI 1998. Malaria in Maremma, Italy. Lancet, 351: 1246-1247.

BARRIENDOS, M. \& J. MARTÍN-VIDE. 1998. Secular climatic oscillations as indicated by catastrophic floods in the Spanish Mediterranean coastal area (14th-19th centuries). Clim. Change, 38: 473-491.

BATE, R. 2004. Climate Change and MosquitoBorne Disease: causal link or green alarmism?. AEI, 2004: 1-6.

BUENO, R. \& R. JIMÉNEZ. 2008. Malaria en España: aspectos entomológicos y perspectivas de futuro. Rev. Esp. Salud Pública, 82: 467-479.

BURGUERS, T. 1949. El arboretum forestal de Villarejo. Rev. de Montes, 29: 400-404.

CHIN, T. \& P. D. WELSBY. 2004. Malaria in the UK: past, present and future. Postgrad. Med. J., 80: 663-666.

CIRUJANO, S. \& L. MEDINA. 2002. Plantas acuáticas de las lagunas y humedales de CastillaLa Mancha. Junta de Comunidades de Castilla-La Mancha. Madrid. 340 pp.

CONSEJERÍA DE MEDIO AMBIENTE. 2002. Plan Andaluz de Humedales. Junta de Andalucía, Sevilla. 218 pp.
COROMINAS, J. 1997. Breve Diccionario Etimológico de la Lengua Castellana. Gredos. Madrid. 627 pp. CUADROS, J., M. J. CALVENTE, A. BENITO, J. ARÉVALO, M. A. CALERO, J. SEGURA \& J. M. RUBIO. 2002. Plasmodium ovale malaria acquired in central Spain. Emerg. Infect. Dis., 8: 1506-1508.

DE LA LAMA, G. 1941. Memoria de reconocimiento y propuesta de trabajos de la finca "Coto Ibarra" (Informe Técnico). Patrimonio Forestal del Estado. 45 pp.

DE LA LAMA, G. 1951. Diez años de trabajos forestales. Rev. de Montes, 39: 195-201.

DE LA LAMA, G. 1976. Atlas del Eucalipto. I.C.O. N.A. Sevilla.

DÍAZ, J., F. BALLESTER \& R. LÓPEZ-VÉLEZ. 2005. Impactos sobre la salud humana. In: Evaluación preliminar de los impactos en España por efecto del Cambio Climático. J. M. Moreno Rodríguez (ed.): 727-772. Ministerio de Medio Ambiente.

ELVIRA, B. \& A. ALMODÓVAR. 2001. Freshwater fish introductions in Spain: facts and figures at the beginning of the 21 st century. J. Fish Biol., 59: 323-331.

ESPINA, J. \& A. ESTÉVEZ. 1993. El espacio de repoblación de Cabezudos-Abalario. In: Intervenciones Públicas en el Litoral Atlántico andaluz. Efectos territoriales. M. Granados \& J. F. Ojeda (eds.): 95-107. Agencia de Medio Ambiente. Sevilla.

FABREGAT, E. 2007. Arroz, paludismo y técnica en el Delta del Ebro (1850-1960). VIII Congreso de la Asociación de Demografía Histórica. 30 mayo, 1-2 Junio. Maó (Menorca). 1-33.

FERNÁNDEZ ASTASIO, B. 2002. La erradicación del paludismo en España: aspectos biológicos de la lucha antipalúdica. Ph. D. Thesis. Universidad Complutense de Madrid, 436 pp.

FERNÁNDEZ ZAMUDIO, R. 2005. Estudio de la flora, vegetación y cambios en el paisaje de la laguna de Las Madres (Huelva). Tesis de licenciatura. Universidad de Sevilla, $431 \mathrm{pp}$.

FERNÁNDEZ ZAMUDIO R., A. SOUSA. \& P. GARCÍA MURILLO. 2007. Laguna de las Madres (Huelva). Flora y Vegetación. Consejería de Medio Ambiente. Sevilla. 287 pp.

GARCÍA-BARRÓN, L. \& M. F. PITA. 2004. Stochastic analysis of time series of temperature in the south-west of the Iberian Peninsula. Atmósfe$r a, 17: 225-244$.

GARCÍA-BARRÓN, L. 2007. La evolución climática del Suroeste de la Península Ibérica basada 
en registros instrumentales. In: Climate Change in Andalucía: trends and environmental consequences. A. Sousa, L. García-Barrón \& V. Jurado (eds.): 81-95. Consejería de Medio Ambiente.

GARCÍA-MURILLO, P. 2006. Reconstruction of the Abalario Landscape. A referent model for environmental restoration in Doñana. In: Doñana. Water and Biosphere. F. García Novo \& C. Marín Cabrera (eds.): 283-287. Ministerio de Medio Ambiente.

HAY, S. I., J. COX, D. J. ROGERS, S. E. RANDOLPH, D. I. STERNK, G. D. SHANKS, M. F. MYERS \& R. W. SNOW. 2002a. Climate change and the resurgence of malaria in the East African highlands. Nature, 415: 905-909.

HAY, S. I., J. COX, D. J. ROGERS, S. E. RANDOLPH, D. I. STERNK, G. D. SHANKS, M. F. MYERS \& R. W. SNOW. 2002b. Reply to Regional warming and malaria resurgence. Nature, 420:628.

HERASO, J. 1890. Estudio sobre la fijación de las dunas situadas en el término municipal de Almonte, provincia de Huelva. Primera Parte. Rev. de Montes, 322: 281-287.

INEbase. 1858. Anuario Estadístico de España, p. VII. National Institute of Statistics Document Collection. National Institute of Statistics.

INEbase. 1915. Anuario Estadístico de España, p. 524. National Institute of Statistics Document Collection. National Institute of Statistics.

INEbase. 1917. Anuario Estadístico de España, p. 543. National Institute of Statistics Document Collection. National Institute of Statistics.

INEbase. 1955. Anuario Estadístico de España, p. 751. National Institute of Statistics Document Collection. National Institute of Statistics.

INEbase. 1961. Anuario Estadístico de España, p. 782783. National Institute of Statistics Document Collection. National Institute of Statistics.

INEbase. 1964. Anuario Estadístico de España, p. 331. National Institute of Statistics Document Collection. National Institute of Statistics.

KITH, M. 1936. Propuesta de ampliación del proyecto de fijación y repoblación de las Dunas de Almonte. V División Hidrológico-Forestal del Guadalquivir. Documento técnico., 15 pp.

KUHN, K. G., D. H. CAMPBELL, B. ARMSTRONG \& C. R. DAVIES. 2003. Malaria in Britain: past, present, and future. PNAS, 19:9997-10001.

LOEVINSOHN, M. E. 1994. Climatic warming and increase malaria incidence in Rwanda. Lancet, 343: 714-718.
LINDSAY, S. W. \& C. J. THOMAS. 2001. Global warming and risk of vivax malaria in Great Britain. Glob. Change \& Human Health, 2: 80-84.

LÓPEZ, S. 1989. Control integral de mosquitos en Huelva. Consejería de Salud y Servicios Sociales de la Junta de Andalucía. Sevilla, 340 pp.

MADOZ, P. 1848.Diccionario Geográfico-estadísticohistórico de España y sus posesiones de Ultramar. Edición facsímil de las voces de la provincia de Huelva. Sánchez Zorro, D. (ed). Ámbito Ediciones (reimpresión 1988). Salamanca. 132 pp.

MARTENS, P. 2000. Malaria and Global Warming in Perspective? Emerg. Infect. Dis., 6: 313-314.

MCCARTHY, J. J., O. F. CANZIANI, N. A. LEARY, D. J. DOKKEN \& K. S. WHITE. 2001. Climate Change 2001: impacts, adaptation, and vulnerability. Contribution of Working Group II to the Third Assessment Report of Intergovernmental Panel on Climate Change. Cambridge University Press. Cambridge. 1100 pp.

MOUCHET, J., S. MANGUIN, S. LAVENTURE, O. FAYE, A. W. ONAPA, P. CARNEVALE, J. JULVEZ \& D. FONTENILLE. 1998. Evolution of Malaria in Africa for the past 40 years: impact of climate and human factors. J. Am. Mosquito Contr., 14: 121-130.

NCHINDA, T. 1998. Malaria: a reemerging disease in Africa. Emerg. Infect. Dis., 4: 398-403.

OJEDA, J. F. 1987. Organización del territorio en Doñana y su entorno próximo (Almonte). Siglos XVIII-XX. I.C.O.N.A. Madrid. 459 pp.

PARDO, L. (1948). Catálogo de los Lagos de España. Ministerio de Agricultura. Instituto Forestal de Investigaciones y Experiencias. Madrid. 520 pp.

PARRY, M. L. 2000. Assessment of Potential Effects and Adaptations for Climate Change in Europe: the Europe ACACIA Project. Jackson Environment Institute, University of East Anglia. Norwich. 320 pp.

PATZ, J. A., M. HULME, C. ROSENZWEIG, T. D. MITCHELL, R. A. GOLDBERG, A. K. GITHEKO, S. LELE, A. J. MCMICHAEL \& D. LE SUEUR. 2002. Regional warming and malaria resurgence. Nature, 420: 627-628.

PERDIGUERO, E. 2005. Huerta, arroz y mosquitos: la lucha contra el paludismo en la provincia de Alicante. Cuad. Hist. Esp., 79: 203-235.

PÉREZ RAYA, F. \& J. M. LÓPEZ NIETO. 1991. Vegetación acuática y helofítica de la depresión de Padul (Granada). Acta Botánica Malacitana, 16: 373-389. 
PLETSCH, D. 1965. Informe sobre una misión efectuada en España en septiembre-noviembre de 1963 destinada a la certificación de la erradicación del paludismo. Rev. Sanid. Hig. Pública, 39: 309-367.

RAMSDALE, C. D. \& K. SNOW. 2000. Distribution of the genus Anopheles in Europe. Eur. Mosq. Bull., 7: 1-28.

REITER, P. 2000. From Shakespeare to Defoe: Malaria in England in the Little Ice Age. Emerg. Infect. Dis., 6: 1-11.

REITER, P., C. J. THOMAS, P. M. ATKINSON, S. I. HAY, S. E. RANDOLPH, D. J. ROGERS, G. D. SHANKS, R. W. SNOW \& A. SPIELMAN. 2004. Global warming and malaria: a call for accuracy. Lancet Infect. Dis., 4: 323-24.

RICO-AVELLÓ, C. 1950. La epidemia de paludismo de la postguerra. Rev. Sanid. Hig. Pública, 24: 701737.

RIERA, J. 1982. Estudios y documentos sobre el arroz y paludismo en Valencia (Siglo XVIII). Universidad de Valladolid. Valladolid. 193 pp.

RIERA, J. 1984. Fiebres y paludismo en la España Ilustrada (Félix Ibáñez y la epidemia de La Alcarria 1784-1792). Universidad de Valladolid. Valladolid. 75 pp.

RODRIGO, F. S., M. J. ESTEBAN-PARRA, D. POZO-VÁZQUEZ \& Y. CASTRO-DÍEZ. 1999. A 500 year precipitation record in Southern Spain. Int. J. Clim., 19: 1233-1253.

ROMI, R., G. SABATINELLI, \& G. MAJORI. 2001. Could malaria reappear in Italy? Emerg. Infect. Dis., 7: 915-919.

ROTAECHE, V., G. HERNÁNDEZ \& S. DE MATEO. 2001. Vigilancia epidemiológica del paludismo en España 1996-1999. Bol. Epidemiológico, 9: 21-25.

RUIZ GONZÁLEZ, J. E. 1999. Huelva, según las relaciones enviadas por los párrocos al geógrafo real Tomás López en el siglo XVIII. Diputación Provincial de Huelva. Huelva. 427 pp.

SÁENZ, J. M. \& P. MARSET. 2000. Teoría académica y práctica ciudadana en el paludismo. Las causas de las enfermedades endémicas en Murcia durante el siglo XVIII desde la perspectiva de la administración local. Asclepio, 52: 167-183.
SALLARES, R. 2006. Role of environmental changes in the spread of malaria in Europe during the Holocene. Quat. Int., 150: 21-27.

SEGURA, C. 1990. Introducción. In: Diccionario Geográfico de Andalucía: Sevilla C. Segura (ed.): 3-9. Don Quijote.

SOUSA, A. \& P. GARCÍA-MURILLO. 2001. Can place names be used as indicators of landscape changes? Application to the Doñana Natural Park (Spain). Lands. Ecol., 16: 391-406.

SOUSA, A. \& P. GARCÍA-MURILLO. 2003. Changes in the Wetlands of Andalusia (Doñana Natural Park, SW Spain) at the End of the Little Ice Age. Clim. Change, 58: 193-217.

SOUSA, A., P. GARCÍA MURILLO \& L. GARCÍA BARRÓN. 2006a. Paludismo, cambios climáticos y humedales en el litoral oriental onubense. Aestuaria, 9: 179-204.

SOUSA, A., L. GARCÍA-BARRÓN, J. MORALES \& P. GARCÍA-MURILLO. 2006b. Post-Little Ice Age warming and desiccation of the continental wetlands of the Aeolian sheet in the Huelva region (SW Spain). Limnetica, 25: 57-70.

SOUSA, A., P. GARCÍA-MURILLO, S. SAHIN, J. MORALES. \& L. GARCÍA-BARRÓN. 2009. Wetland place names as indicators of manifestations of recent climate change in SW Spain (Doñana Natural Park). Clim. Change (in press).

TRAN, A., N. PONÇON, C. TOTY, C. LINARD, H. GUIS, J. B. FERRÉ, D. LO SEEN, F. ROGER, S. DE LA ROCQUE, D. FONTENILLE \& T. BALDET. 2008. Using remote sensing to map larval and adult populations of Anopheles hyrcanus (Diptera: Culicidae) a potential malaria vector in Southern France. Int. J. Health Geogr., 7: 9.

TRICK, T. \& E. CUSTODIO. 2003. Hydrodynamic characteristics of the western Doñana Region (area of El Abalario), Huelva, Spain. Hydrogeol. J., 12: 321-335.

WHITE, J. N. \& J. G. BREMAN. 1994. Paludismo y babebiosis. In: Harrison. Principios de Medicina Interna. K. J. Isselbacher, E. Braunwald, J. D. Wilson, J. B. Martin, A. S. Fauci \& D. L. Kasper. (eds.): 10291041. Interamericana y McGraw-Hill. Madrid. 